\title{
The role of work motivation as a mediator on the influence of education-training and leadership style on employee performance
}

\author{
Luisinha Fonseca Da Costa Guterresa ${ }^{a^{*}}, \operatorname{Armanu}^{\mathrm{b}}$ and Rofiaty $^{\mathrm{b}}$
}

${ }^{a}$ Student, Program Doctor of Management Science, Brawijaya of University, Indonesia

${ }^{b}$ Faculty Of Economics and Business, Brawijaya of University, Indonesia

\section{CH R O I C L E ABSTRACT}

Article history:

Received: November 17, 2019

Received in revised format: No-

vember 302019

Accepted: December 16, 2019

Available online:

December 16, 2019

Keywords:

Education-training

Leadership style

Motivation

Employee performance

Ministry of Education

Timor-Leste

\begin{abstract}
This paper offers an empirical study of the role of work motivation in mediating the effect of education-training and leadership style on the performance of Ministry of Education employees in Timor-Leste. Data were obtained from 86 employees as samples through questionnaires. We applied the SEM-PLS to analyze the proposed relationship model. Empirical results show that work motivation mediated the influence of leadership style on employee performance, but not for educationtraining. The results can provide valuable insight for public service management.
\end{abstract}

\section{Introduction}

Timor-Leste, which had been part of the State of Indonesia since 1976 under the name Timor-Timor, officially became an independent and sovereign state in 2002. This country began its independence among the poorest countries in the world and the quality of public services has not undergone significant changes. From various studies of public services in Timor-Leste (Blunt, 2009; Marriott, 2012; Parker, 2009; Shah, 2011; Wilson, 2012) apparently there was not reforms carried out in various sectors so that the country's economic growth gets better (Shah, 2012; World Bank, 2015). Since its independence, population growth in Timor-Leste along with relatively moderate GDP growth have led to decrease in per capita income and increase in poverty rates (Lundahl \& Sjöholm, 2009). Facing this situation, the focus of attention is on the quality of human resources. With the end of the UN mission in post-conflict Timor-Leste in December 2012, there have been some opportunities for state development in practice. Progress has varied, from building state bureaucracies and government machinery, democracy and participation, building institutions including the rule of law, and controlling corruption and transparency (Goldfinch \& Derouen Jr, 2014). In this era of globalization, modern business primarily are driven by intellectual capital and human capital helps organizations build and maintain competitive advantage (MacDougall \& Hurst, 2005). Munawaroh, Riantoputra, and Marpaung (2013) identified the factors that influence employee performance, including individual performance, quantity and quality of work, responsibilities and needs for achievement. Education-Training is one measure of employee development. The right type of education is very important for skill development and its effectiveness depends on training pedagogy (Dubey \& Gunasekaran, 2015). For education-training programs to be successful and achieve their goals, (1) training process must be designed in such a way to give confidence to participants so that they can apply in the workplace; (2) it is necessary to

* Corresponding author.

E-mail address: lya_fon99@yahoo.com (L.F.D.C.Guterresa)

(C) 2020 by the authors; licensee Growing Science, Canada doi: $10.5267 /$ j.msl.2019.12.017 
provide practical examples of the knowledge and skills to be applied in conditions that simulate the actual work environment of employees; and (3) there is a need to present the 'framework' of behavior that employees must follow so that training content can be implemented efficiently in their work (Diamantidis \& Chatzoglou, 2014). In community service-oriented organizations, such as the Ministry of Education Office, organizational success is highly dependent on the role of the leader, because leaders influence the emotions, attitudes and behavior of employees (Avolio, Gardner, Walumbwa, Luthans, \& May, 2004) and how employees interact with service users (Wallace, de Chernatony, \& Buil, 2013).

\section{Literature review}

\subsection{Education-Training}

Capabilities, skills, and competencies are very important for employees to work effectively and efficiently. To realize this, it is necessary to empower human resources as planners and implementers in organizations, one of which is to provide education-training to employees. The education-training program for employees is expected to provide motivation for employees to improve their performance skills so that they can further improve their work performance (Hidayat \& Budiatma, 2018). In a different context, previous research has shown that education-training is able to change the way a person views his work. For example, education-training motivates entrepreneurial performance (Bhardwaj, 2014; Cheraghi \& Schøtt, 2015). Therefore, the first hypothesis is proposed:

$\mathrm{H}_{1}$ : Education-training is positively related to employee motivation.

Employee ability is an integral part of the entire human resource system. These abilities include reading, writing, mathematics, computer skills and software, problem solving, critical thinking, the ability to participate in meetings, and report writing (Ferguson \& Reio, 2012). Lack of employee skills can affect productivity, accidents, errors, and increased costs of rework (Clinton, 1999). There is an opinion that training is important not only because it is needed to build and maintain an effective workforce, but also because it encourages corporate well-being and improves organizational performance (Saks \& Burke Smalley, 2014; Salas \& Cannon-Bowers, 2001). However, participants must first apply and transfer what they learn in training at work. Previous studies confirmed the existence of a positive relationship between education-training with individual or group performance, both for private employees (Aliman, 2017; Sendawula, Nakyejwe Kimuli, Bananuka, \& Najjemba Muganga, 2018) and civil servants. Studies on education-training in the public sector have been carried out a lot, especially since the education-training program is one program that is intended to empower civil servants. Therefore, the second hypothesis is proposed:

$\mathrm{H}_{2}$ : Education-training affects employee performance through motivation.

\subsection{Leadership Style}

Work motivation has been alluded to in several studies that relate it to transformational leadership (misalnya, Kahai, Sosik, \& Avolio, 2003; Manik, 2016; Mathieu \& Babiak, 2015; Zareen, Razzaq, \& Mujtaba, 2015). Koh and Hia (1997) found hypothesis support for employee motivation, commitment and their trust in leaders in the Singapore banking industry. Schaubroeck, Lam, and Peng (2011) show that the influence of leader behavior on team performance is fully mediated by the beliefs and psychological state of the team. Özaralli (2003) found that transformational leadership contributes to the prediction of subordinate empowerment and that the more team members experience team empowerment, the more effective the team will be. Burns (1978), the originator of transformational leadership theory, proposes that transformational leaders are compared to transactional leaders, motivating their followers in such a way that their main motive is to fulfill self-actualization needs rather than other needs that are lower in Maslow's hierarchy of needs. Transformational leaders expand their "portfolio of needs" in Maslow's hierarchy of needs theories. Bass (1985) argues that the followers' extra effort shows how much leaders motivate them to act outside contractual expectations. Thus, the emphasis on satisfying self-actualization needs reflects the types of needs that underlie the motivation of followers, and extra effort results from higher levels of motivation (Dvir, Eden, Avolio, \& Shamir, 2002). Therefore, the following third hypothesis is proposed:

\section{$\mathrm{H}_{3}$ : Leadership style affects employee motivation.}

The success of an organization is determined by many things, including leadership styles that take place within the organization. The leader is said to be successful if he is able to become the creator or driver of his subordinates by creating a work atmosphere that can spur the growth and development of the performance of his subordinates. Such leaders have the ability to have a positive effect on their subordinates to do appropriate work directed in order to achieve the stated goals. Leadership behavior influences subordinates' performance, as supported in the findings of previous research (Landry \& Vandenberghe, 2012). The meta-analysis of Judge and Piccolo (2004) reports that leadership styles are positively correlated with group and organizational performance. Transformational leadership theory explains that leaders as agents of change are able to produce performance beyond expectations by assigning challenging tasks to direct and motivate themselves and others to achieve higher levels of performance (Bass, Avolio, Jung, \& Berson, 2003; Masi \& Cooke, 2000). Team collectivism shows a better positive effect of transformational leadership on team potential (Braun, Peus, Weisweiler, \& Frey, 2013; Schaubroeck, Lam, 
\& Cha, 2007). Wang et al. (2011) have also confirmed the positive influence of transformational leadership on team performance and for each level of the organization. Transformational leaders also motivate and inspire followers to achieve performance beyond expectations by changing attitudes, beliefs, and values of their followers (Abdullah, 2018; Rafferty \& Griffin, 2004). The direct influence of transformational leadership on subordinates' performance has also been confirmed in Krisnanda and Surya (2019). While in different settings, a number of researchers show an indirect relationship between leadership style and subordinate performance, which is mediated by organizational culture (Sinaga, Asmawi, Madhakomala, \& Suratman, 2018), work environment (Imran, Fatima, Zaheer, Yousaf, \& Batool, 2012), job-fit (Chi \& Pan, 2012), conflict (Kammerhoff, Lauenstein, \& Schütz, 2019), training (Nasser \& Aini, 2016), leader-subordinate exchange (Wang, Law, Hackett, Wang, \& Chen, 2005), employee involvement (Buil, Martínez, \& Matute, 2019; Hee, Ibrahim, Kowang, \& Fei, 2018; Schmitt, Den Hartog, \& Belschak, 2016), self-efficacy (Walumbwa \& Hartnell, 2011), behavior of organizational citizenship (Boerner, Eisenbeiss, \& Griesser, 2007), knowledge sharing (Masa'deh, Obeidat, \& Tarhini, 2016), organizational commitment (Chu \& Lai, 2011), trust (Braun et al., 2013; Schaubroeck et al., 2011), work motivation (Manik, 2016; Mavhungu \& Bussin, 2017), and job satisfaction (Biswas \& Varma, 2011; Hasmin, 2017). If a leader is able to combine appropriate and effective leadership styles within the organization, this will give employees a sense of empowerment and as a result, employees can carry out their duties more efficiently and effectively so that their creative and innovative abilities spur, which ultimately lead on improving performance. The importance of motivating employee work from the leadership style applied is to improve employee performance. This assumption is supported by the results of Manik (2016); Mavhungu and Bussin (2017). Therefore, the fourth hypothesis is proposed:

$\mathrm{H}_{4}$ : Leadership style affects employee performance through motivation.

\subsection{Employee Motivation}

Work motivation is an inner strength that encourages employees to achieve personal and organizational goals (Lindner, 1998). Previous findings have proven that individuals who are motivated in their work will have a positive impact on improving their performance (Arifin, 2015; Manik, 2016). The importance of motivating civil servants in public organizations has been discussed in previous studies (Caillier, 2014; Mann, 2006; Paarlberg \& Lavigna, 2010; Petrovsky \& Ritz, 2014). Motivation of public services refers to the motives of employees to do good for others and shape people's welfare (Perry, Hondeghem, \& Wise, 2010, p. 3). This also means as trust, values and attitudes that go beyond self-interest and the interests of the organization. Therefore, the fifth hypothesis is proposed:

$\mathrm{H}_{5}$ : Employee motivation affects employee performance.

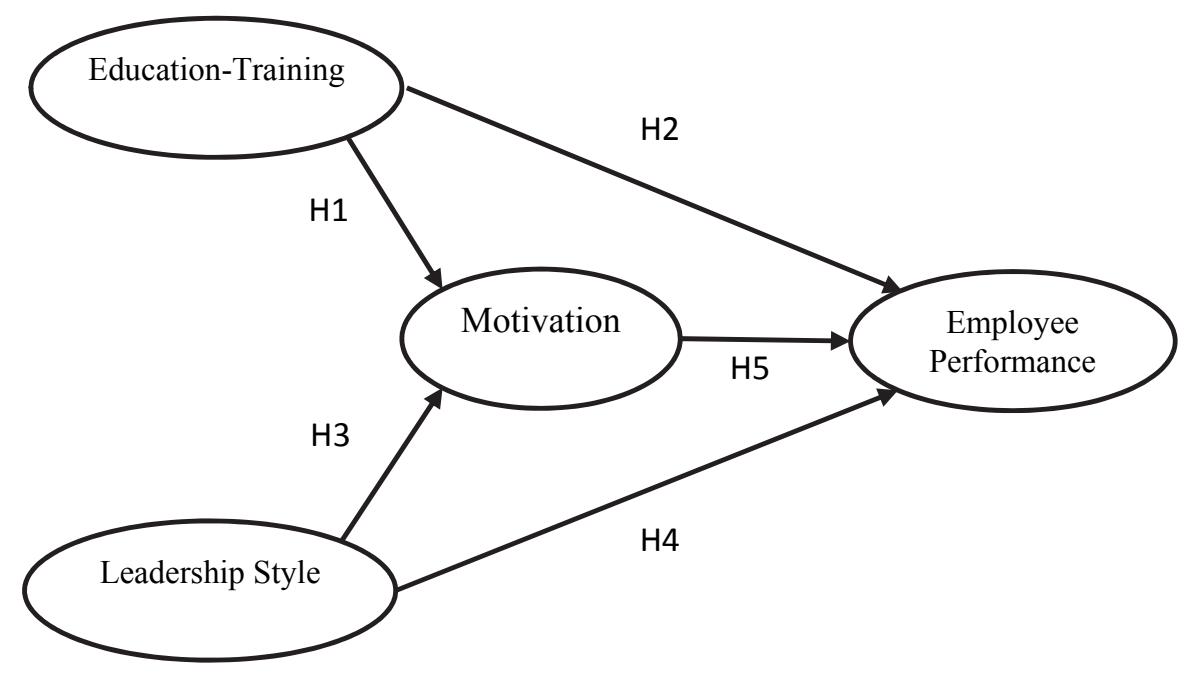

\section{Methods}

Fig. 1. Conceptual Framework

This research is a type of explanatory research, which intends to explain the position of the variables studied and the relationships between variables. The purpose of this study is to explain the role of work motivation in mediating the effect of education-research and leadership style on employee performance. The research was carried out at the Office of the Ministry of Education of the Democratic Republic of Timor-Leste (República Democrática de Timor-Leste) with Civil Servants (Funcionário Público) in five directorates as research respondents. The choice of location is supported by several reasons. First, the education sector has a very important role in preparing quality human resources in developing national development in Timor Leste. Second, the scarcity of current research that investigates the behavior of public organizations in Timor Leste, especially in the Ministry of Education sector. Third, the results of this study are expected to provide information and practical 
implications for the phenomenon of employee performance at the Ministry of Education Office, Timor-Leste. The population in this study included all employees totaling 436 employees. The sampling technique uses no probability sampling with Purposive-judgment sampling type. This study uses an analytical tool in the form of Structural Equation Modeling (SEM) with the Partial Least Square (PLS) approach. SEM-PLS tests the causal relationship between the research variables which have not had much theoretical support or the research is explanatory. The steps in the PLS analysis consist of an evaluation of the structural model measurement and evaluation model, based on Hair et al. (2014).

\section{Results and discussion}

\subsection{Measurement Evaluation}

In estimating and testing the proposed research model, we followed the two-step procedure suggested by Anderson and Gerbing (1988). Structural equation modeling or SEM with SmartPLS is used to analyze survey data. Table 1 shows that the Cronbach's alpha and composite reliability coefficients of the construct exceed the rule of thumb rules which are generally known to be 0.70 (Fornell \& Larker, 1981; O'Leary-Kelly \& Vokurka, 1998). Thus, we conclude that our theoretical constructs show adequate reliability. We build a measurement model through PLS algorithm procedures to assess convergent validity of each measurement scale (O'Leary-Kelly \& Vokurka, 1998). Table 1 shows that all indicators in each construct have a significant factor loading $(\mathrm{p}<0.01)$ greater than 0.50 , which indicates convergent validity of theoretical constructs (Anderson $\&$ Gerbing, 1988).

Table 1

Construct Reliability and Validity Results

\begin{tabular}{|c|c|c|c|c|c|}
\hline Variables & Indicators & Loadings & Alpha & CR & AVE \\
\hline \multirow{2}{*}{ Education-Training } & Formal & 0.902 & 0.774 & 0.868 & 0.687 \\
\hline & Non-Formal & 0.826 & 0.66 & 0.854 & 0.745 \\
\hline \multirow{2}{*}{ Leadership Style } & Transformational & 0.977 & 0.832 & 0.89 & 0.671 \\
\hline & Transactional & 0.618 & 0.596 & 0.818 & 0.696 \\
\hline \multirow{3}{*}{ Work Motivation } & Esteem Needs & 0.771 & 0.475 & 0.792 & 0.655 \\
\hline & Self-Actualization Needs & 0.937 & 0.793 & 0.866 & 0.617 \\
\hline & Safety Needs & 0.727 & 0.687 & 0.86 & 0.756 \\
\hline \multirow{5}{*}{ Employee Performance } & Quality & 0.78 & 0.671 & 0.818 & 0.601 \\
\hline & Quantity & 0.833 & 0.688 & 0.829 & 0.619 \\
\hline & Timeliness & 0.839 & 0.707 & 0.836 & 0.631 \\
\hline & Effectivity & 0.794 & 0.735 & 0.882 & 0.79 \\
\hline & Independence & 897 & 0.796 & 0.868 & 0.623 \\
\hline
\end{tabular}

\subsection{Structural evaluation}

Based on Table 2, the direct effect of education-training on work motivation results in a coefficient value of 0.038 , and the $\mathrm{t}$ statistical value (0.317) is smaller than the specified t-table value (1.96). That is, there is no significant direct effect of education-training on work motivation. Thus, the first hypothesis $\left(\mathrm{H}_{1}\right)$ is rejected. The direct effect of education-training on employee performance results in a coefficient value of 0.313 , and a t-statistic value (3.784) which is greater than the specified $t-$ table value (1.96). That is, there is a significant direct effect of education-training on employee performance. However, the indirect effect of education-training on employee performance through work motivation produces a coefficient of 0.010 , and a t-statistic value (0.316) which is smaller than the specified t-table value (1.96). That is, there is no significant effect of education-training on employee performance through work motivation. Thus, the second hypothesis $\left(\mathrm{H}_{2}\right)$ is rejected. The direct influence of leadership style on work motivation results in a coefficient value of 0.322 , and a t-statistic value (5.041) that is greater than the specified t-table value (1.96). That is, there is a significant direct effect of leadership style on work motivation. Thus, the third hypothesis $\left(\mathrm{H}_{3}\right)$ is accepted. The direct influence of leadership style on employee performance produces a coefficient value of 0.300 , and a t-statistic value (2.736) which is greater than the specified t-table value (1.96). That is, there is a significant direct effect of leadership style on employee performance.

Likewise, the indirect influence of leadership style on employee performance through work motivation results in a coefficient of 0.087 , and a t-statistic value (2.978) which is greater than the specified t-table value (1.96). That is, there is a significant effect of leadership style on employee performance through work motivation. Thus, the fourth hypothesis $\left(\mathrm{H}_{4}\right)$ is accepted.

The direct effect of work motivation on employee performance produces a coefficient value of 0.269 , and a t-statistic value (3.691) which is greater than the specified t-table value (1.96). That is, there is a significant direct effect of work motivation on employee performance. Thus, the fifth hypothesis $\left(\mathrm{H}_{5}\right)$ is accepted. 


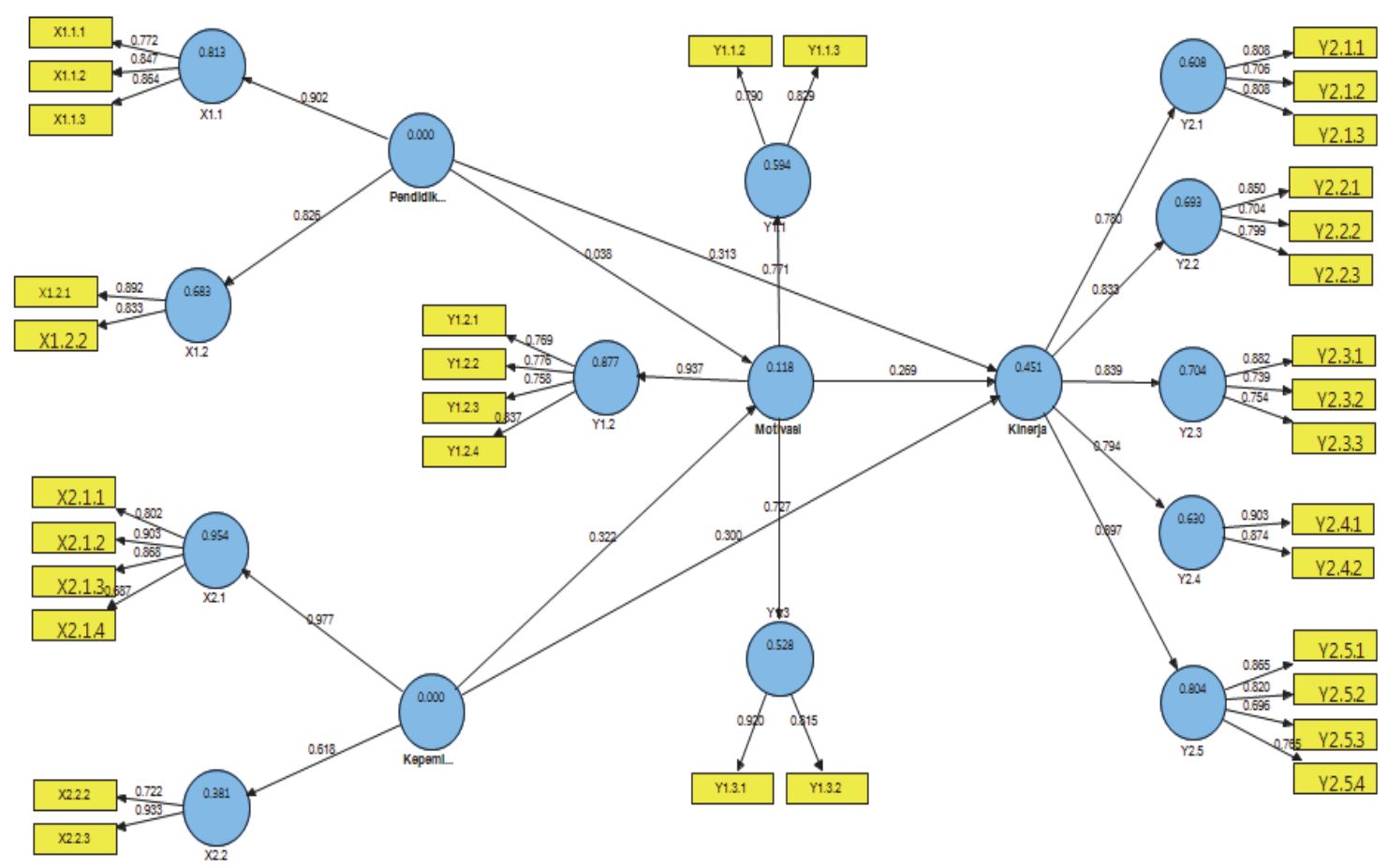

Fig. 2. Structural Equation Modeling Results

Table 2

PLS Results of the Structural Model

\begin{tabular}{|c|c|c|c|c|c|c|}
\hline Exogen Variable & Moderator & Endogen Variable & $\begin{array}{l}\text { Direct Effect } \\
\text { (t-value) }\end{array}$ & $\begin{array}{l}\text { Indirect Effect } \\
\text { (t-value) }\end{array}$ & VAF & Conclusion \\
\hline Education-Training & - & Work motivation & $0,038(0.317)$ & - & - & H1 rejected \\
\hline Education-Training & Work motivation & Employee Performance & $0,313(3.784)$ & $0.010(0.316)$ & 0.031 & $\mathrm{H} 2$ rejected \\
\hline Leadership Style & - & Employee Performance & $0.322(5.041)$ & - & - & H3 accepted \\
\hline Leadership Style & Work Motivation & Employee Performance & $0,300(2.736)$ & $0.087(2.978)$ & 0.224 & H4 accepted \\
\hline Work Motivation & - & Employee Performance & $0,269(3.691)$ & - & - & H5 accepted \\
\hline
\end{tabular}

\section{Conclusion}

The results of the study have provided a general conclusion that work motivation mediates the influence of leadership style on employee performance, but does not mediate the effect of education-training on employee performance at the Ministry of Education Office of Timor-Leste. There are five specific conclusions from the results of this study. First, education-training has no effect on work motivation, which indicates that although there is an increase in education-training but it does not directly increase employee motivation. Second, education-training does not affect employee performance through work motivation, which indicates that work motivation does not mediate the effect of education-training on employee performance. Third, leadership style influences work motivation, which shows that when the leadership style properly is applied it will directly increase employee motivation. Fourth, leadership style influences employee performance through work motivation which shows that work motivation mediates the effect of leadership style applied to employee performance. Fifth, work motivation has an effect on employee performance, which shows that better work motivation will directly improve employee performance.

The results of this study have indicated that the performance of employees at the Ministry of Education Office of Timor-Leste was directly influenced by education-training, leadership style and work motivation. An effective and efficient leadership style can motivate employees so that employees can work better which can ultimately improve their performance. Even though the employee is not motivated by the education-training program provided by the organization, the education-training of employees remains an important factor that determines the level of employee performance. So, organizations do not provide education-training programs to motivate employees to improve their performance, but the organization helps employees improve the intelligence and skills of employees in their jobs. 


\section{References}

Abdullah, E. (2018). Transformational leadership, technical competencies and self-efficacy on employee performance (A subsidiary of Dana Pensiun Bank Mandiri Empat-DPBME). Jurnal Manajemen, 9(1), 12-22.

Aliman, A. (2017). Education and training in enhancing performance of Indonesia Port Corporation employees. International Journal of Managerial Studies and Research (IJMSR), 5(1), 24-27.

Anderson, J. C., \& Gerbing, D. W. (1988). Structural equation modeling in practice: A review and recommended two-step approach. Psychological Bulletin, 103(3), 411.

Arifin, H. M. (2015). The influence of competence, motivation, and organisational culture to high school teacher job satisfaction and performance. International Education Studies, 8(1), 38-45.

Avolio, B. J., Gardner, W. L., Walumbwa, F. O., Luthans, F., \& May, D. R. (2004). Unlocking the mask: a look at the process by which authentic leaders impact follower attitudes and behaviors. The Leadership Quarterly, 15(6), 801-823.

Bass, B. M. (1985). Leadership and Performance Beyond Expectations. New York, NY: Free Press.

Bass, B. M., Avolio, B. J., Jung, D. I., \& Berson, Y. (2003). Predicting unit performance by assessing transformational and transactional leadership. Journal of Applied Psychology, 88(2), 207.

Bhardwaj, B. R. (2014). Impact of education and training on performance of women entrepreneurs: a study in emerging market context. Journal of Entrepreneurship in Emerging Economies, 6(1), 38-52. doi:10.1108/jeee-05-2013-0014

Biswas, S., \& Varma, A. (2011). Antecedents of employee performance: an empirical investigation in India. Employee Relations, 34(2), 177-192.

Blunt, P. (2009). The political economy of accountability in Timor Leste: Implications for public policy. Public Administration and Development: The International Journal of Management Research and Practice, 29(2), 89-100.

Boerner, S., Eisenbeiss, S. A., \& Griesser, D. (2007). Follower behavior and organizational performance: The impact of transformational leaders. Journal of Leadership and Organizational Studies, 13(3), 15-26.

Braun, S., Peus, C., Weisweiler, S., \& Frey, D. (2013). Transformational leadership, job satisfaction, and team performance: A multilevel mediation model of trust. The Leadership Quarterly, 24(1), 270-283.

Buil, I., Martínez, E., \& Matute, J. (2019). Transformational leadership and employee performance: The role of identification, engagement and proactive personality. International Journal of Hospitality Management, 77, 64-75.

Burns, J. M. (1978). Leadership. New York, NY: Harper \& Row.

Caillier, J. G. (2014). Toward a better understanding of the relationship between transformational leadership, public service motivation, mission valence, and employee performance: A preliminary study. Public Personnel Management, 43(2), 218239.

Cheraghi, M., \& Schøtt, T. (2015). Education and training benefiting a career as entrepreneur: gender gaps and gendered competencies and benefits. International Journal of Gender and Entrepreneurship, 7(3), 321-343.

Chi, N.-W., \& Pan, S.-Y. (2012). A multilevel investigation of missing links between transformational leadership and task performance: The mediating roles of perceived person-job fit and person-organization fit. Journal of Business and Psychology, 27(1), 43-56.

Chu, L.-C., \& Lai, C.-C. (2011). A research on the influence of leadership style and job characteristics on job performance among accountants of county and city government in Taiwan. Public Personnel Management, 40(2), 101-118.

Clinton, M. S. (1999). An examination of basic skills education and its effect on performance. Journal of Education for Business, 74(5), 266-270.

Diamantidis, A. D., \& Chatzoglou, P. D. (2014). Employee post training behaviour and performance: evaluating the results of the training process. International Journal of Training and Development, 18(3), 149-170.

Dubey, R., \& Gunasekaran, A. (2015). Education and training for successful career in big data and business analytics. Industrial and Commercial Training, 47(4), 174-181.

Dvir, T., Eden, D., Avolio, B. J., \& Shamir, B. (2002). Impact of transformational leadership on follower development and performance: A field experiment. Academy of Management Journal, 45(4), 735-744.

Ferguson, K. L., \& Reio, T. G. (2012). Human resource management systems and firm performance. Journal of Management Development, 29(5), 471-494.

Fornell, C., \& Larker, D. F. (1981). Evaluating structural equation models with unobservable variable sand measurement error. Journal of Marketing Research, 18(1), 39-50.

Goldfinch, S., \& Derouen Jr, K. (2014). In It For The Long Haul? Post Conflict Statebuilding, Peacebuilding, And The Good Governance Agenda In Timor Leste. Public Administration and Development, 34(2), 96-108.

Hair, J. F., Jr., Hult, G. T. M., Ringle, C. M., \& Sarstedt, M. (2014). A Primer on Partial Least Squares Structural Equation Modeling (PLS-SEM): Sage.

Hasmin, E. (2017). Effect of transformational leadership on employee job satisfaction and performance. SSRN Electronic Journal. doi:10.2139/ssrn.2968062

Hee, O. C., Ibrahim, R., Kowang, T. O., \& Fei, G. C. (2018). Employee engagement as a mediator between transformational leadership and employee performance. Asian Journal of Scientific Research, 11(3), 441-448.

Hidayat, R., \& Budiatma, J. (2018). Education and job training on employee performance. International Journal of Social Sciences and Humanities, 2(1), 171-181. 
Imran, R., Fatima, A., Zaheer, A., Yousaf, I., \& Batool, I. (2012). How to boost employee performance: investigating the influence of transformational leadership and work environment in a Pakistani perspective. Middle-East Journal of Scientific Research, 11(10), 1455-1462.

Judge, T. A., \& Piccolo, R. F. (2004). Transformational and transactional leadership: A meta-analytic test of their relative validity. Journal of Applied Psychology, 89(5), 755.

Kahai, S. S., Sosik, J. J., \& Avolio, B. J. (2003). Effects of leadership style, anonymity, and rewards on creativity-relevant processes and outcomes in an electronic meeting system context. The Leadership Quarterly, 14(4-5), 499-524.

Kammerhoff, J., Lauenstein, O., \& Schütz, A. (2019). Leading toward harmony - Different types of conflict mediate how followers' perceptions of transformational leadership are related to job satisfaction and performance. European Management Journal, 37(2), 210-221.

Koh, W. K. L., \& Hia, H. S. (1997). The effects of interactive leadership on human resource management in Singapore's banking industry. The International Journal of Human Resource Management, 8(5), 710-719.

Krisnanda, P. H., \& Surya, I. B. K. (2019). Effect of emotional and spiritual intelligence on transformational leadership and impact on employee performance. International Research Journal of Management, IT and Social Sciences, 6(3), 70-82.

Landry, G., \& Vandenberghe, C. (2012). Relational commitments in employee-supervisor dyads and employee job performance. The Leadership Quarterly, 23(3), 293-308.

Lindner, J. R. (1998). Understanding employee motivation. Journal of Extension, 36(3), 1-8.

Lundahl, M., \& Sjöholm, F. (2009). Population growth and job creation in Timor-Leste. Journal of the Asia Pacific Economy, 14(1), 90-104.

MacDougall, S. L., \& Hurst, D. (2005). Identifying tangible costs, benefits and risks of an investment in intellectual capital: Contracting contingent knowledge workers. Journal of Intellectual Capital, 6(1), 53-71.

Manik, E. (2016). The influence of transformational leadership on achievement motivation and organizational climate and employee performance. International Journal of Academic Research in Business and Social Sciences, 6(12), $599-608$.

Mann, G. A. (2006). A motive to serve: Public service motivation in human resource management and the role of PSM in the nonprofit sector. Public Personnel Management, 35(1), 33-48.

Marriott, A. (2012). Justice Sector Dynamics in Timor Leste: Institutions and Individuals. Asian Politics \& Policy, 4(1), 5371.

Masa'deh, R. e., Obeidat, B. Y., \& Tarhini, A. (2016). A Jordanian empirical study of the associations among transformational leadership, transactional leadership, knowledge sharing, job performance, and firm performance: A structural equation modelling approach. Journal of Management Development, 35(5), 681-705.

Masi, R. J., \& Cooke, R. A. (2000). Effects of transformational leadership on subordinate motivation, empowering norms, and organizational productivity. International Journal of Organizational Analysis, 8(1), 16-47.

Mathieu, C., \& Babiak, P. (2015). Tell me who you are, I'll tell you how you lead: Beyond the Full-Range Leadership Model, the role of corporate psychopathy on employee attitudes. Personality and Individual Differences, 87, 8-12.

Mavhungu, D., \& Bussin, M. H. (2017). The mediation role of motivation between leadership and public sector performance. SA Journal of Human Resource Management, 15(1), 1-11.

Munawaroh, A., Riantoputra, C. D., \& Marpaung, S. B. (2013). Factors influencing individual performance in an Indonesian government office. The South East Asian Journal of Management, 135-144. doi:10.21002/seam.v7i2.2051

Nasser, F., \& Aini, N. (2016). The impact of transformational leadership style on employee job performance: The mediating effect of training. International Journal of Science and Research (IJSR), 5, 499-503.

O'Leary-Kelly, S. W., \& Vokurka, R. J. (1998). The empirical assessment of construct validity. Journal of Operations Management, 16(4), 387-405.

Özaralli, N. (2003). Effects of transformational leadership on empowerment and team effectiveness. Leadership and Organization Development Journal, 24(6), 335-344.

Paarlberg, L. E., \& Lavigna, B. (2010). Transformational leadership and public service motivation: Driving individual and organizational performance. Public Administration Review, 70(5), 710-718.

Parker, S. (2009). Handle with care: private security companies in Timor-Leste. Dili: Small Arms Survey, the Graduate Institute of International and Development Studies, Geneva and ActionAid, Timor-Leste Armed Violence Assessment / TLAV

Perry, J. L., Hondeghem, A., \& Wise, L. R. (2010). Revisiting the motivational bases of public service: Twenty years of research and an agenda for the future. Public Administration Review, 70(5), 681-690.

Petrovsky, N., \& Ritz, A. (2014). Public service motivation and performance: A critical perspective. Evidence-based HRM: a Global Forum for Empirical Scholarship, 2(1), 57-79.

Rafferty, A. E., \& Griffin, M. A. (2004). Dimensions of transformational leadership: Conceptual and empirical extensions. The Leadership Quarterly, 15(3), 329-354.

Saks, A. M., \& Burke Smalley, L. A. (2014). Is transfer of training related to firm performance? International Journal of Training and Development, 18(2), 104-115.

Salas, E., \& Cannon-Bowers, J. A. (2001). The science of training: A decade of progress. Annual Review of Psychology, 52(1), 471-499.

Schaubroeck, J., Lam, S. S., \& Cha, S. E. (2007). Embracing transformational leadership: Team values and the impact of leader behavior on team performance. Journal of Applied Psychology, 92(4), 1020. 
Schaubroeck, J., Lam, S. S., \& Peng, A. C. (2011). Cognition-based and affect-based trust as mediators of leader behavior influences on team performance. Journal of Applied Psychology, 96(4), 863.

Schmitt, A., Den Hartog, D. N., \& Belschak, F. D. (2016). Transformational leadership and proactive work behaviour: A moderated mediation model including work engagement and job strain. Journal of Occupational and Organizational Psychology, 89(3), 588-610.

Sendawula, K., Nakyejwe Kimuli, S., Bananuka, J., \& Najjemba Muganga, G. (2018). Training, employee engagement and employee performance: Evidence from Uganda's health sector. Cogent Business \& Management, 5(1), 1470891.

Shah, R. (2011). It takes two (or more) to tango: Partnerships within the education sector in Timor-Leste.

Shah, R. (2012). Goodbye conflict, hello development? Curriculum reform in Timor-Leste. International Journal of Educational Development, 32(1), 31-38.

Sinaga, H. G., Asmawi, M., Madhakomala, R., \& Suratman, A. (2018). Effect of change in management, organizational culture and transformational leadership on employee performance PT. Adhya Tirta Batam. International Review of Management and Marketing, 8(6), 15-23.

Wallace, E., de Chernatony, L., \& Buil, I. (2013). Building bank brands: How leadership behavior influences employee commitment. Journal of Business Research, 66(2), 165-171.

Walumbwa, F. O., \& Hartnell, C. A. (2011). Understanding transformational leadership-employee performance links: The role of relational identification and self efficacy. Journal of Occupational and Organizational Psychology, 84(1), 153172.

Wang, G., Oh, I.-S., Courtright, S. H., \& Colbert, A. E. (2011). Transformational leadership and performance across criteria and levels: A meta-analytic review of 25 years of research. Group and Organization Management, 36(2), $223-270$.

Wang, H., Law, K. S., Hackett, R. D., Wang, D., \& Chen, Z. X. (2005). Leader-member exchange as a mediator of the relationship between transformational leadership and followers' performance and organizational citizenship behavior. Academy of Management Journal, 48(3), 420-432.

Wilson, B. V. (2012). To 2012 and beyond: International assistance to police and security sector development in Timor Leste. Asian Politics \& Policy, 4(1), 73-88.

World Bank. (2015). Country data report for Timor-Leste, 1996-2014 (English) (105586). Retrieved from Washington, D.C.: http://documents.worldbank.org/curated/en/242671468195839145/Country-data-report-for-Timor-Leste-1996-2014

Zareen, M., Razzaq, K., \& Mujtaba, B. G. (2015). Impact of transactional, transformational and laissez-faire leadership styles on motivation: A quantitative study of banking employees in Pakistan. Public Organization Review, 15(4), 531-549.

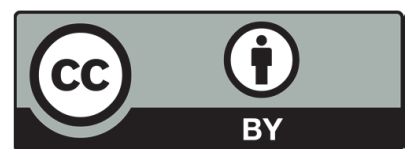

(C) 2020 by the authors; licensee Growing Science, Canada. This is an open access article distributed under the terms and conditions of the Creative Commons Attribution (CC-BY) license (http://creativecommons.org/licenses/by/4.0/). 